\title{
A görkorcsolyázás története II.
}

\section{Roller-skate in history II.}

10.21486/recreation.2012.2.4.2

Absztrakt - A görkorcsolya, mely első megjelenése óta folyamatosan fejlődik, formálódik, rendkívüli változatosságot mutat formai jegyei tekintetében. A cél melyre használták és használják, azonban mit sem változott az idők folyamán. A görkorcsolyával megvalósítható mozgás fő célja ritka esetek kivételével nem az A pontból B pontba eljutásra korlátozódik, mindamellett, hogy praktikusságát, gyorsaságát, alkalmazhatóságát tekintve felveszi a versenyt a kerékpárral is akár, hanem sokkal inkább a mozgásos öröm és élményszerzés. A görkorcsolya megjelenési formái, a történelem során kialakult változatai egyrészt folyamatos technikai fejlődést mutatnak, ahogy az egyes feltalálók saját kútfőből, vagy mások ötleteit tovább javítgatva fejlesztettek, másrészt időről időre új irányzatok is megszületnek. Ennek a folyamatos fejlődésnek a terméke az a változatosság, mellyel e guruló eszköz még hatékonyabban járul hozzá az elsődleges célhoz a mozgásos örömszerzéshez, végső soron az egészséges és boldog élethez. Jelen áttekintő cikk az egy-, két-, három-, a különleges négy-, és sokkerekű korcsolyák történelmi fejlődését hivatott bemutatni, mely ismeret adalékul szolgálhat a soros és párhuzamos korcsolyák fejlődéstörténetének átfogóbb, pontosabb szemléléséhez.

Kulcsszavak: görkorcsolya, görkorcsolyázás, egysoros, párhuzamos, történet.

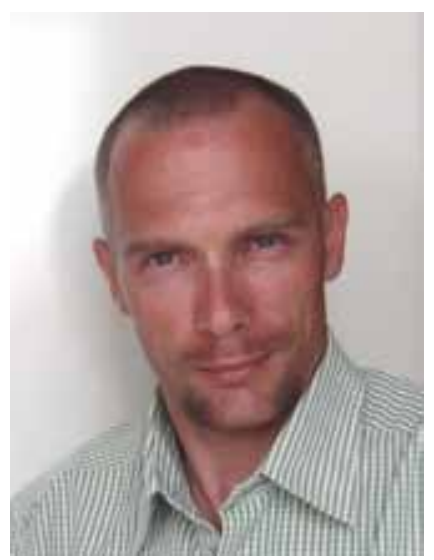

Szerző:

BÉRES SÁNDOR Ph.D. Egyetemi docens

Eszterházy Károly Főiskola, Testnevelés és Sporttudományi Intézet Eger

\section{BEVEZETÉS}

A görkorcsolyázás története I. című tanulmányban bemutatásra került a görkorcsolya eredete, kezdeti évei és fejlődésének szakaszai az első próbálkozásoktól, a fékek és a golyóscsapágyak szabadalmaztatásáig. Az olvasó betekintést nyerhetett abba, hogy az egyes szabadalmakon keresztül, hogyan tökéletesedett, fejlődött a görkorcsolya két meghatározó formája a soros és a párhuzamos fajta. Az ezernyolcszázas években azonban az ipari forradalom korában egymást érték az újabbnál újabb találmányok. A feltalálók a kerékpározásnak és a lovaglás alternatívájaként egyre érdekesebb elképzeléseket vetettek papírra és valósítottak meg a lábakra szerelhető, kerekek segítségével való haladás érdekében.

\section{AZ EGYKEREKÜ GO̊RKORCSOLYÂK}

Az egysoros és párhuzamos korcsolyák sikerén felbuzdulva jött létre aPedospeed elnevezésü rendkívül érdekes, a görkor- 
csolya utánzat is, melyet a Scientific American címú amerikai lap 1870. március 19.-i kiadványa közöl. Az Illinois állambéli, Olney város lakója, THOMAS L. LUDERS és fia,1869. május 4.-én, a 89833-as szabadalmi számmal ${ }^{1}$ bejegyzi új találmányát a Pedospeedet, másnéven az egykerekü korcsolyát. A cikk szerint, a feltalálók nemes egyszerüséggel besétálnak a szerkesztőségbe, ahol az idősebbik Luders nekilát, hogy elmagyarázza az eszköz müködését, mialatt a fiatalabb a lábára erősíti az eszközt és demonstrálja működését (Karmelek, 2012).

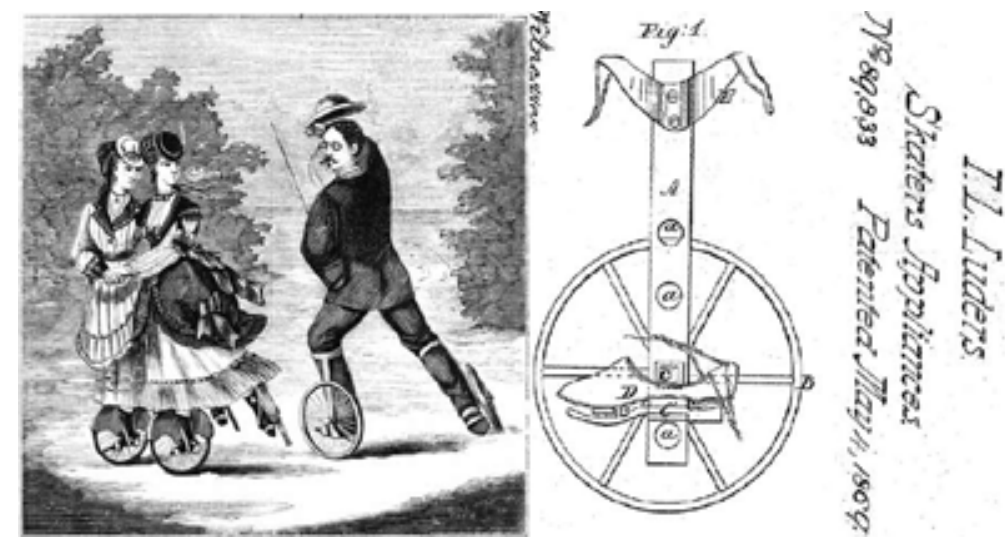

1. ábra Thomas L. Luders és fia által szabadalmaztatott Pedospeed, melyet a Scientific American c. lapban mutat be 1870-ben(Karmelek, 2012)(Mitskevichus, 2011)

\section{Abstract:}

Abstract - The tool, which has been fluently improved and formed from its first appearance shows a very large variety in its form. However, the purpose of its usage did not change in the course of time. It is not to get from point $A$ to point $B$, except in rare cases, though roller skate can be a match for the bicycle, but much rather the joy and experience of motion. The forms and types of roller skate in history have shown continuous technical evolution on one hand and from time to time new trends wereraising on the other hand. The product of this continuous evolution is that variety, which contributes more effectively to the primary purpose to enjoy motion and in the end to lead a healthy and happy life. This survey is dedicated to present the historical evolution of the one-, two-, three-, special four- and many wheeled roller skates, which is a help to have a better and more efficient view on the historical background of inline and roller skates.

Keywords: skating, roller-skate, inline-skate, history
A Pedospeed kerekeinek átmérője 35-38cm,azok egy-egy kengyelhez kapcsolódnak, melyeket egy nyúlvány segítségével egy hickory fából készült rúddal az alszárakhoz rögzítenek. A nyúlvány egy fémlemez, mely úgy van az alszárat fogó farúdhoz rögzítve, hogy a láb egy tengely segítségével elöre-hátra elmozdulhasson.

A korabeli írások úgy pozícionálják Pedospeedet, hogy azok az otthonülök, akik nem tudtak megtanulni a Parlor görkorcsolyával görkorcsolyázni, a Pedospeeddel elsőre gurulni fognak, sőt nagyszerủen manőverezni és akár olyan felületen is haladni, ahol a hagyományos görkorcsolya tudománya már megáll.

„Bárki bátran használhatja a Pedospeedet, nem kell tőle tartani...” - írja a korabeli reklámszöveg - „....a feltaláló nagydarab, súlyos ember és arról számol be, hogy akár két órán át, fáradtság nélkül tudja használni az eszközt." Az eszköz előnyeit tovább ecsetelendő, a reklám felhívja a figyelmet, hogy hölgyek számára olyan keréktakaró lemez helyezhetö fel a kerekekre (a képen látható módon - 1.ábra), mely megakadályozza, hogy a ruhájuk összepiszkolódjon, vagy beakadjon.

A következő egykerekü görkorcsolyát szinte az elsővel egy időben szabadalmaztatták. Az USA, Ohio államból származó HIRAM L. TRUE 1877. április 3.-án, 189.285-ös számmal jegyezteti be a Luders-ék szerkezetéhez nagyon hasonlító, szintén egykerekű guruló eszközt. Ez az alkalmatosság a köztudatba Parlorskate-ként (szalon görkorcsolya), vagy Velocipedeparlor-skate-ként (kerékpárszalon görkorcsolya) kerül.
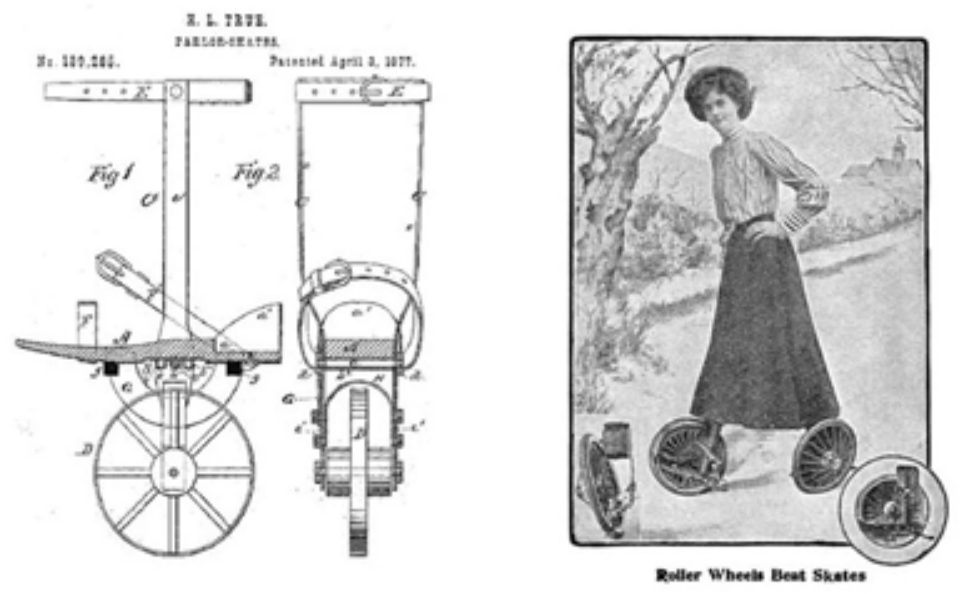

2. ábra VelocipedeParlor korcsolya, melynek feltalálója H. L. True. Amerikai szabadalmi száma 189.285. Szabadalmaztatási dátum1877.április 3. (Mitskevichus, 2011)

Nem sokkal később 1908-ban, a Journal of Popular Mechanics-ben megjelenik egy cikk egy svájci mérnökröl, aki egy újabb egykerekű korcsolyával áll elö, melyet „úthenger korcsolyának" nevez el. Mitskevichus, a forrás szerzője sajnos nevet és képet nem közöl erröl az érdekesnek tűnő találmányról, azonban hozzáteszi, 40 év sem telik el és az egykerekü

\footnotetext{
${ }^{1}$ (Mitskevichus, Очерки по истории изобретений, 2011)
} 
görkorcsolyák csillaga hosszú időre teljesen leáldozik, mivel teljesen eltünnek a köztudatból.

Mitskevichus-al (2011) ellentétben, Karmelek (2012) azt írja: „Amíg a párhuzamos (quad) görkorcsolyák időről-időre megszűnnek létezni a nagyközönség érdeklődését illetően, addig az egykerekü korcsolyák folyamatos sikernek örvendenek. A szerző egyébként honlapján több olyan videót mutat be (pl. egy rendkívül érdekes 1923-ban² korabeli filmkamerával rögzített kisfilmet), melyben az eredeti pedospeed használat tünik fel. ${ }^{3} \mathrm{E}$ filmecskében érdekes módon a kerekeket nem kívülre - 1. ábra - szerelt módon, hanem a két láb közé szíjazva használják, de láthatóan a szerkezet ettől nagyszerüen müködik. A szereplők földúton, erdőben, a mai Nordikwalkingnál ${ }^{4}$ használatos botokkal hajtják magukat. A honlapon további kisfilmek mutatják be az egykerekűek jelenkori „feltámadásait” (3. ábra).

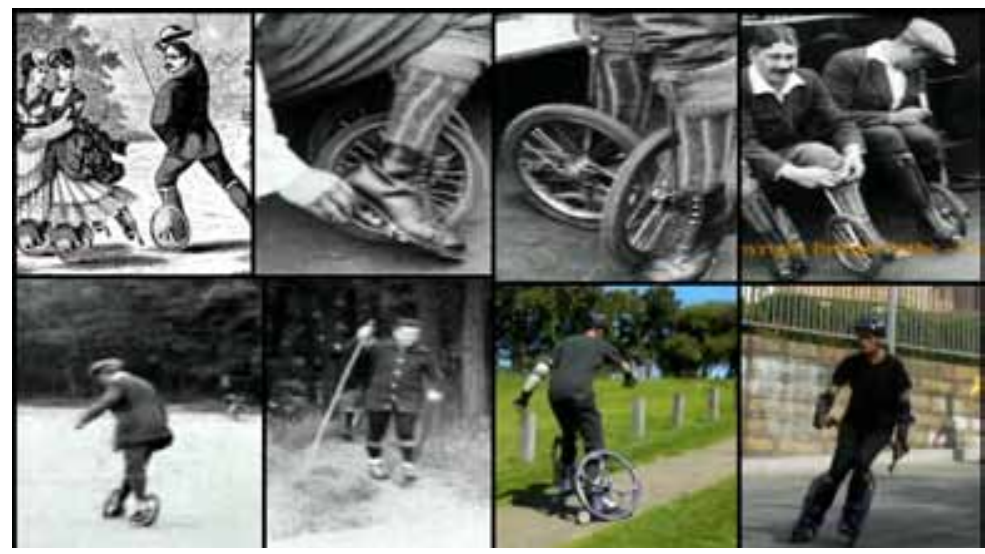

3. ábra A Pedospeed alkalmazása a kezdetekben, a 20-as években és manapság (képek forrásai a következő videók ${ }^{5.6}$ )

Az elkövetkező években különböző feltalálók apróbb fejlesztgetéseket hajtanak végre az egykerekü korcsolyán, de forradalmi változás már nem történik. A következő képen (4. ábra) látható szabadalmak alapos tanulmányozásával jól megfigyelhetőek a szerkezet tökéletesítésére tett törekvések (fogaskerék, rugós lengéscsillapítás, gumi kerékabroncs stb.).

\section{KÉTKEREKƯ GÖRKORCSOLYÁK}

A kétkerekű korcsolyák elöretörését, elterjedését talán az is elősegíthette, hogy egy hétköznapi ember számára az egy kerék ránézésrebizonytalanabbnak tünhet. A kétkerék, az mégiscsak kétkerék. Két alátámasztási pont, annak ellenére, hogy elmozdul,nagyobb bizalmat, stabilitást sugall,mint az egy. Ebből a megfontolásból kiindulva (egy évvel az első soros amerikai görkorcsolya szabadalom beadása után), 1861-ben ALBERT ANDERSON találmánya is megkapta a szabadalmi számát, mely 33.689 lett. Meg kell jegyezni, nem sokkal ezután jelent meg a Plimpton féle párhuzamos négykerekű (quad) görkorcsolya is, 1863-ban.

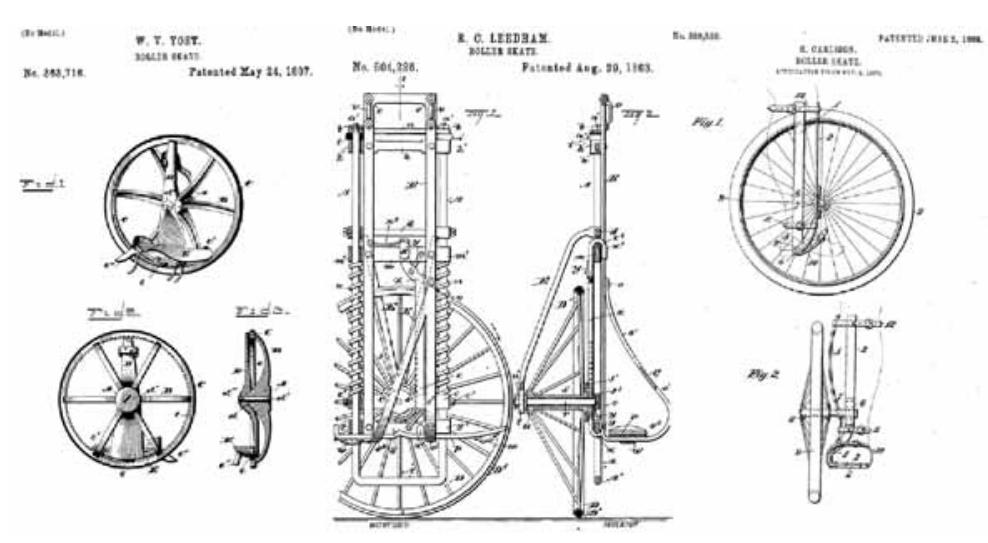

4. ábra Az egykerekü görkorcsolyák további szabadalmai. Szabadalmi számok 363.716 (1887), 504.226 (1893), 889.580 (1908). Forrás: (Mitskevichus, Очерки по истории изобретений, 2011)

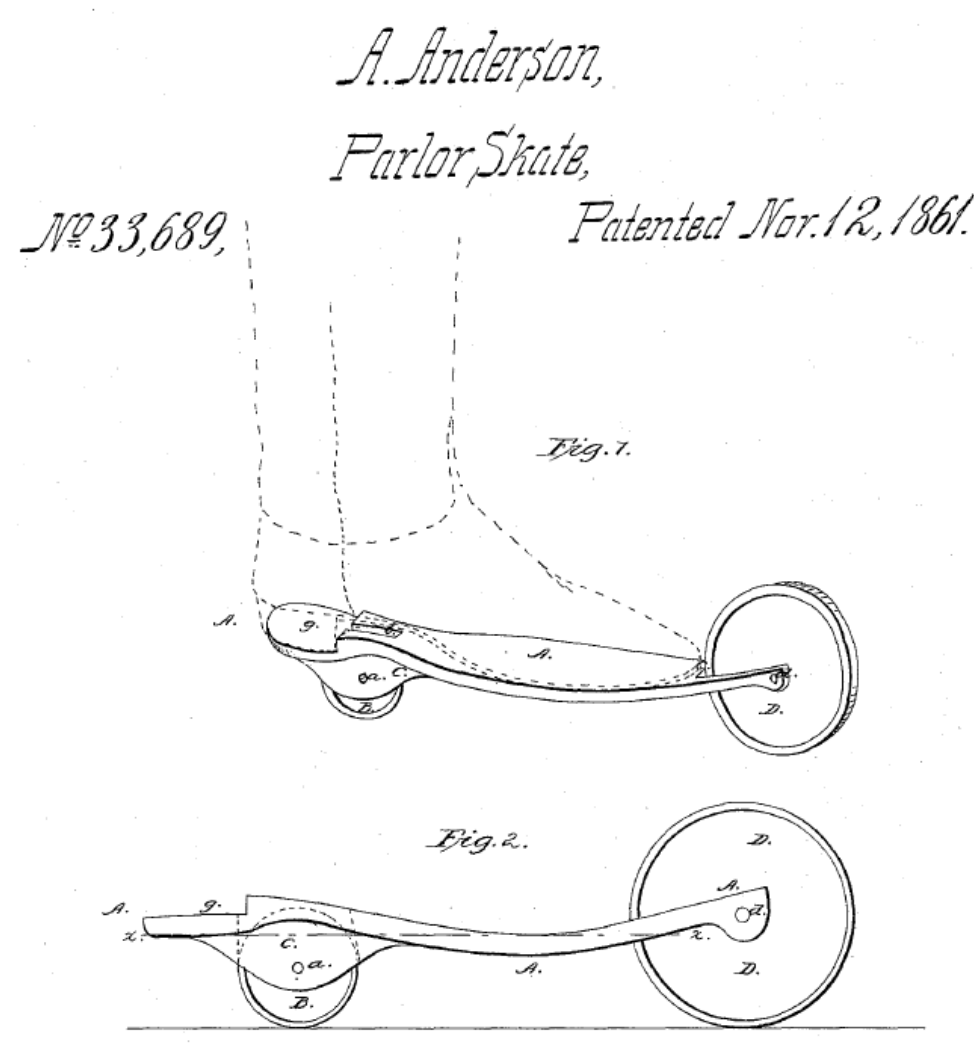

5. ábra A. Anderson 1861-ben szabadalmaztatott, 33.689-es számú kétkerekü görkorcsolyája

\footnotetext{
${ }^{2}$ http://www.britishpathe.com/video/a-new-sport-cycle-skating

${ }^{3} \mathrm{http}: / /$ blogs.scientificamerican.com/anecdotes-from-the-archive/2012/03/19/ over-100-years-later-an-old-invention-takes-a-new-spin/

${ }^{4}$ (Wikipédia, 2012)

${ }_{5}^{5}$ (BritishPaté, 2012),http://www.britishpathe.com/video/a-new-sport-cycle-skating

${ }^{6}$ (ChariotSkates, 2011), http://youtu.be/3tazyrZG-Sc
} 
A forrás szerzője (Mitskevichus, 2011) megjegyzi, hogy közvetlenül az ANDERSON féle szabadalom bejegyzése után több hasonló jellegű kétkerekű görkorcsolya is megjelenik, de nehéz megítélni az egyesült államokbeli népszerüségüket, mert ebben az időszakban a párhuzamos (quad) görkorcsolyák uralják a piacot, és az érdeklődést leginkább ezek iránt kiterjedt. Valószínűsíthető, hogy Európában e kétkerekű korcsolyák nagyobb népszerüségnek örvendek, melya század vége felé még nő is.

llyen, rendkívül népszerü korcsolya volt az 1896-ban megjelenő, RICHARD-CHOUBERSKY féle Patin Bicyclette, vagy úti görkorcsolya (RoadSkates) (Oldbike.eu, 2011).

CHARLES CHOUBERSKY a francia feltaláló egy rendkívül érdekes személy volt. Hivatását tekintve „kommunikációs mérnök", másnéven vasút specialista és feltaláló. 1835-ben Tulában született, édesapja köztiszteletben álló vasút szakértő, aki akkortáit a helyi fegyvergyár építési munkálatai miatt költözött oda. Choubersky már korán fogékonynak mutatkozott az új dolgok tervezése, készítése iránt és már tíz éves korában az örökmozgó elkészítése foglalkoztatta. Ezt felismerve és támogatva édesapja először elküldi az Imperial St.PetersburgLyceumba, mely átirányítja az Institute of theCorps of Communications Engineers intézetbe. Miután 1851-ben a harmadik legjobb eredménnyel felvételizik, iskoláját négy éven keresztül osztályelsőként járja ki, és 1855-ben kitüntetéssel végez.

Először Bécsben, Brüsszelben, majd Párizsban él, ahol rengeteg hasznos dolgot talál fel. A "mobil” kandalló feltalá-

lása, mely Choubersky kályha néven

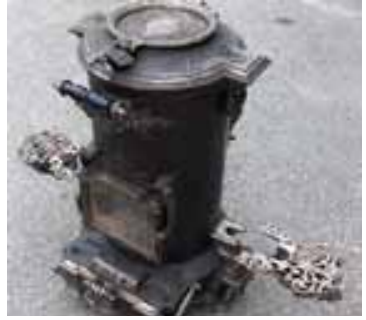

7. ábra A "mobil" kandalló vagy más néven Choubersky kályha ${ }^{8}$

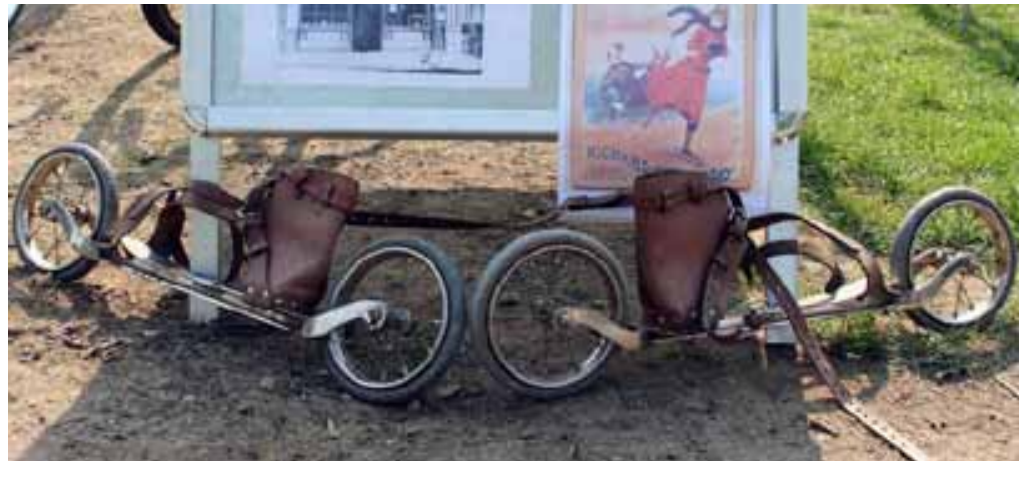

6. ábra RICHARD-CHOUBERSKY féle Patin Bicyclette, úti görkorcsolya (RoadSkates) ${ }^{7}$

Choubersky találmányai által világhírre tett szert. Párizsban különösen népszerű volt, olyannyira, hogy a kortárs hírességeket bemutató „Historie du Siecle” 1789-1889, melyet Párizs 1889-ben rendezett Nemzetközi Kiálításán mutattak be, megemlíti őt mint a párizsi kortárs celebritások egyikét. Ennek ellenére sem a népszerüség, sem az anyagi komfort nem elégítette ki. Életével gyakran tűnt elégedetlennek különösen utolsó éveiben. Ez magyarázza öngyilkosságát is. 1891 novemberében Párizsban, 57 évesen főbe lőtte magát.

A görkorcsolyázás története szempontjából meghatározó találmánya a RoadSkates hozzájárult világhírnevéhez és a század egyik leghíresebb személye lett, köszönhetően a találmánynak, de föleg annak a jól eltalált poszternek, melyen egy, a kétkerekűvel korcsolyázó hölgy látható, háttérben egy hátsóra esett jégkorcsolyázó férfivel. Az eredeti példányokból, még ma is fellelhető néhány, de mára már nagyon kevés maradt belölük.

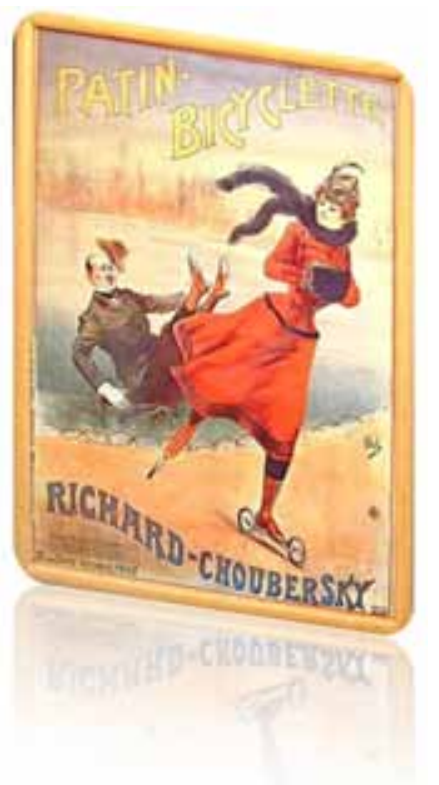

8. ábra A Choubersky poszter

Minden évben elköltött közel százezer frankot találmányai különböző képeslapokban való hirdetéseire. Ezek cikkek, képek vagy versikék voltak.

Három saját üzlete volt Párizsban, melyekben találmányait árulta, és röviddel halála után megnyitotta a negyediket is a Montmartre Boulevard-on, mely figyelemreméltóan elegáns és szép volt, minden részletét tekintve. A bronz szobrokat, tüzhelyeket neves müvészek és müépítők tervezték, olyanok, mint pl. Gamier az új párizsi opera építésze.

Utolsó évei során a feltaláló leginkább arra koncentrált, hogy a legegyszerübb tárgyakat fejlesztgesse, mivel azt vallotta, hogy a nagy találmányoknak rendszerint kisebb hasznukat veszik az emberek, mint a mindennapokra kifejlesztett tárgyaknak. 
ANDREW PECK és IRVING SNYDER 1866-ban alapította meg a Peck\&Snyder sportfelszereléseket gyártó társaságát New Yorkban, a Nassau str. 124-128-ban. 1900-ban viszonylag korán sikeresek lettek találmányukkal, az első gumitalpú, textil felsőrésszel rendelkező sportcipővel, ill. a szabadalmaztatott, kétkerekü, egysoros görkorcsolyával. A korcsolya acél alváza középen szétcsúsztatható volt, melyeket csavarral rögzíteni lehetett, így állítható mérete miatt, többféle lábméretre is alkalmazható volt.

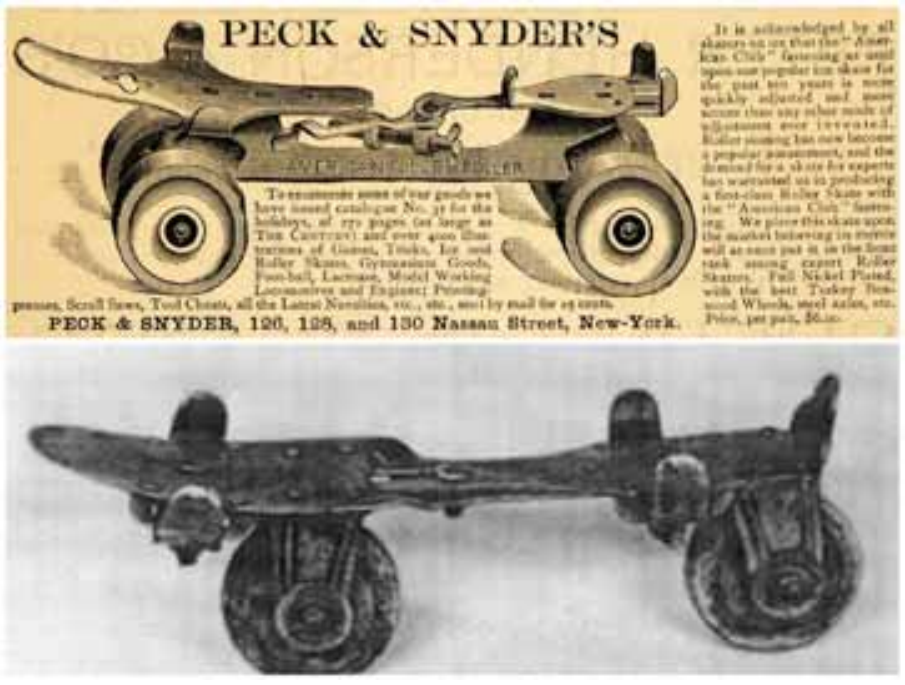

9. ábra A Peck\&Snyder kétkerekü korcsolya (1900), a felső képen a négykerekes továbbfejlesztett változat. forrás:(kzcrew.com, 2008)

Azokban az években nem csak Amerikában, hanem Angliában is készültek érdekes, népszerü görkorcsolyák. Ilyen volt a The RoadSkate Co. által gyártott Ritter vagy más néven RoadSkate „úti” görkorcsolyák. A találmány gyártása és értékesítése tehát az ő érdemük, ugyanakkor egy svájci mérnök tervezte, akit RITTERnek hívtak. A korcsolya konkurenseivel szemben hamar a népszerübb lett. Az időpont 1896-1898. E platform görkorcsolya speciális klipekkel rögzült a cipő talpára. Kerekei csapágyazottak voltak, és a kerékpáréhoz hasonlatos fékrendszerrel is el volt látva, de ezt egy kábellel lehetett müködésbe hozni.
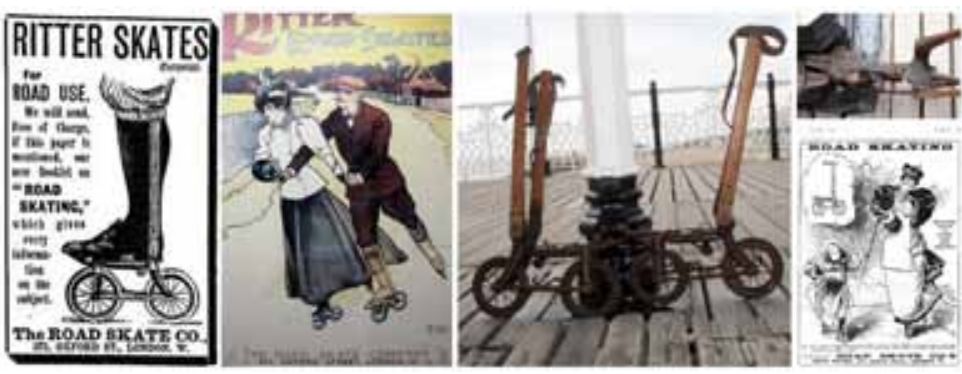

10. ábra A RoadSkatemelyet a sváci feltaláló Ritter tervezett meg és a RoadSkate Co. értékesített ${ }^{9}$ (BuyVintage, 2008),

(Mitskevichus, Роликовые коньки - roller skates (окончание), 2011)
Meg kell említeni, hogy ez a szerkezet feltünően hasonlít a Görkorcsolyázás története I. cikkben már említett William Lockwood amerikai feltaláló által tervezett és 1876-ban szabadalmaztatott görkorcsolyára(szabadalmi száma 182.835). A plagizálás vádját elkerülendő, a feltaláló azzal védekezett, hogy egyrészt a Lockwoodkorcsolya szabadalmaztatása már 20 évetörtént és lejárt, másrészt egy másik országban került bejegyzésre. A helyzet mindenesetre rendkívül furcsa volt. Amerikában a görkorcsolyák hasonló kialakítása a nem terjedt el igazán, míg Angliában később közel húsz változata jelent meg, bár áttörést jelentő újítást egyiksem hozott. ${ }^{10}$

A kétkerekű korcsolyák nagy előnye, hogy szinte az összes példány alkalmas szabadtéren, sőt földúton, vagy terepen való használatra is. A történeti vonulatot kicsit most félretéve kerül bemutatásra az elődök legutolsó dédunokája, ha úgy tetszik, ami gyökereit tekintve visszanyúlik az elődök tervezési irányvonalához. Ez a terepgörkorcsolya a LandRoller, melyet kaliforniai cég jegyzett be és gyárt.

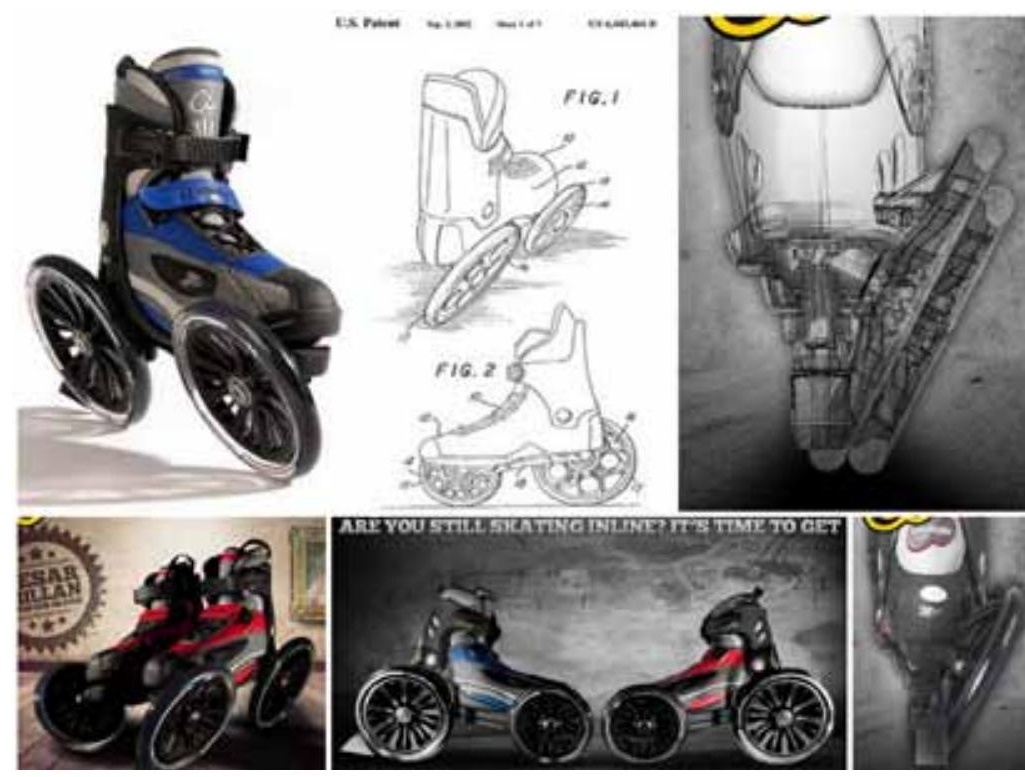

11. ábra A kaliforniai Landroller Inc. kétkerekü terepgörkorcsolyája a Landroller(Landroller, 2012)(Mitskevichus,

Роликовые коньки - roller skates (окончание), 2011)

A LandRoller egy meglehetősen szokatlan dizájn. A kerekek oldalt helyezkednek el, a merölegeshez képest 30fokos dőlésszögben, viszonylag nagyméretűek és pontosan a talp középvonala alatt érintik a talajt. Azért van szükség az ilyen elrendezésre, hogy a lehető legnagyobb kereket alkalmazhassák. A túl kicsi kerekek ugyanis alkalmatlanná teszik a görkorcsolyát a terepen való gurulásra. A nagy kerekekkel, magas fekvő tengelyekkel e korcsolya kiválóan alkalmas az akár füben való haladásra is, mivel a nagy átmérőjü kerekek könnyedén birkóznak meg az út egyenetlenségeivel, anélkül, hogy bármilyen csillapítást alkalmazna a gyártó. ${ }^{11}$

\footnotetext{
${ }^{9}$ (BuyVintage, 2008)

${ }^{10}$ (Mitskevichus, Роликовые коньки - roller skates (окончание), 2011)

11 (Mitskevichus, Роликовые коньки - roller skates (окончание), 2011)
} 


\section{HÁROMKEREKÜ ÉS EGYÉB GÖRKORCSOLYÁK}

A tervezők olykor előállnak olyan tanulmányokkal, melyek nem hoznak igazán nagy sikert. llyen irányvonal volt a háromkerekü görkorcsolyák tervezése és gyártása. Ha nem a talp alá egy sínbe vannak sorjázva a kerekek, akkor elhelyezésére sok variációs lehetőség nincs. A három kerék ésszerüen a talp alá helyezve háromszög alakzatba rendezhető oly módon, hogy egy elöl és kettő hátul, vagy fordítva. A talp két oldalára helyezve szintén csak a 2-1 elrendezés lehetséges. A forrás szerint a háromkerekű elrendezéssel egy időben több próbálkozás is volt, de annak sikertelensége miatt, hamar elfogytak az új tervek.
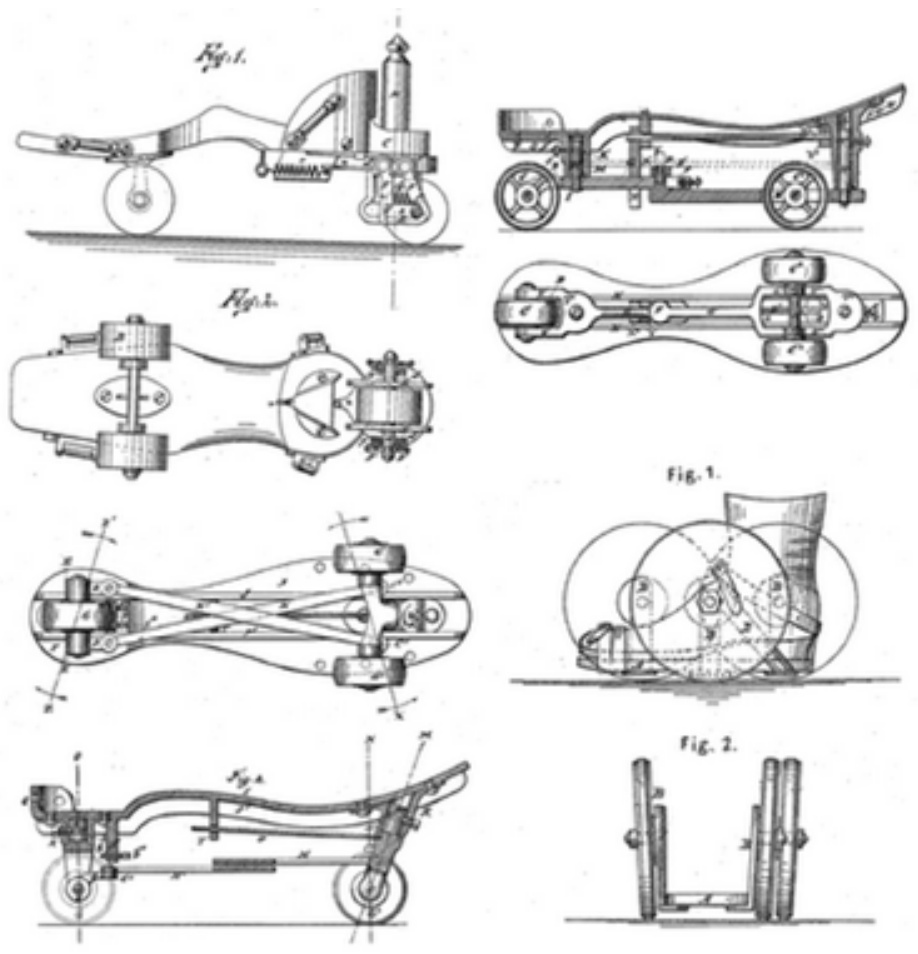

12. ábra Háromkerekủ görkorcsolya tervek. A rajzok USAban bejegyzett szabadalmi számi: 98117 (1869 év), 177566 (1876), 177568 (1876), 196230 (1877). (Mitskevichus,

Роликовые коньки - roller skates (окончание), 2011)

A négykerekü, nem soros és nem is klasszikus párhuzamos elrendezést mutató görkorcsolya tervek közül párat a 13. ábra mutat be. Jól megfigyelhetőek a tervezési irányvonalak. A középen kettő, elöl, hátul egy-egy, az elcsúsztatott elrendezés, a kisebb nagyobb kerekek kombinálása, a dupla kerekek stb. Az ábra bal felső sarkában egy új terv látható, mely a régiekből fakadó elrendezést mutat. Sajnos a forrás nem szól, az egyes tervezők kilétéről, vagy ami még ennél is tanulságosabb lenne, az egyes tervek gyakorlati hasznának, használhatóságának finomságairól. Hogy az alábbi korcsolyák milyen gondolati háttérrel születtek meg, valószínűleg soha nem fogjuk már megtudni.
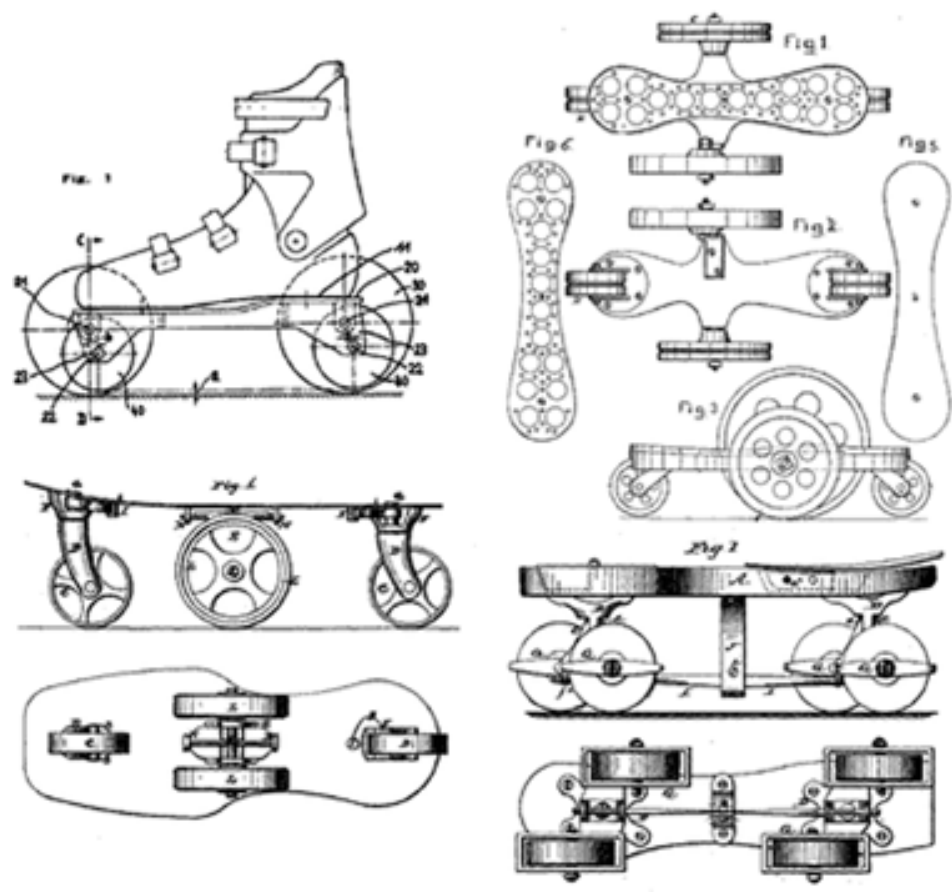

13. ábra Alternatív négykerekü görkorcsolya tervek. A rajzok az USA-ban bejegyzett szabadalmi számai: 188.351 (1877), 233845 (1880), 280236 (1883) 7758054 (2010)

\section{SOKKEREKÜ GÖRKORCSOLYÁK}

1892-ben WALTER NIELSON New Yorkban szabadalmaztatta az ún. „Kombinált jég és görkorcsolyát”. A 14 kerekü korcsolya szabadalmi leírása tartalmaz egy kitételt, mely azt javasolja, hogy „lehetőség szerint egy gumi, bőr, vagy ezekhez hasonlatos anyagú tuskó („,pad”) legyen felszerelhető a korcsolyára...,- „oly módon, hogy ha a korcsolyázó megállni kíván, szükségképp e tuskó a parkettre, vagy talajra nyomásával megtehesse azt". Ezzel a javaslattal a feltaláló némileg megelőzte korát írja a cikk szerzője ${ }^{12}$. Ez persze nem igaz, mint tudjuk, mert 1876-ban a pennsylvánia-i CYRUS WELLINGTON SALADEE már bejegyeztette a gumituskós féket (Herefordshire Roller skating Club, 2012), ugyanakkor a maihoz leginkább hasonlító megoldásról van valóban szó.


14. ábra AWalter Nielson korcsolya. USA-beli szabadalmi száma 480.610(The Inline Planet, 2005), (Mitskevichus, Роликовые коньки - roller skates (окончание), 2011)

\footnotetext{
${ }^{12}$ (Herefordshire Roller skating Club, 2012)
} 
A NIELSON korcsolya nagy valószínüleg nagy siker lehetett az eladások tekintetében. Sajnos ezzel kapcsolatban nem maradt fenn sok adat. 26 évvel később (1918), azonban a gondolat újjá születik (USA szabadalmi szám: 1268385), de immár magasabb technológiai szinten. Ennél a típusnál 16 kereket helyeznek el a sínben, ill. azokat jó minőségű tengelyekkel és csapágyakkal látják el. Ez a korcsolya nyilvános siker abban a tekintetben, hogy több újság is foglalkozik vele, mint például az 1920-ban megjelent Popular Science.

Folytatás a Görkorcsolyázás története 3. című cikkben.

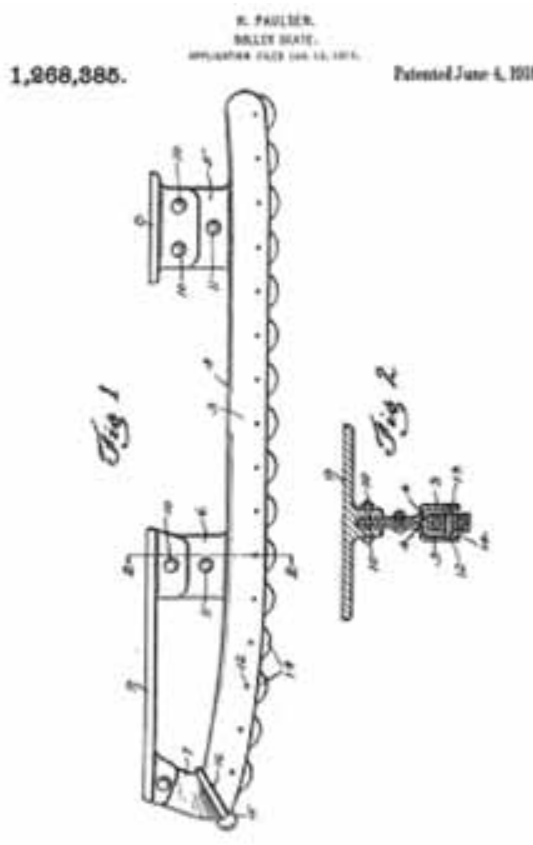

You Can Ice-Skate on the Sidewalk Now

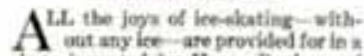
Newe invented by Ularry Paulen,

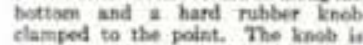
und for pirouerting and the rolle! allowa a fesilility of motion that is tert peasible win the entinary raller. State on these diate you cas make


At fins glance Mt. Puilen'x shate lookt the the opdinary ienakats fer the rollers are slinon coneraind te ruechly in in plact by

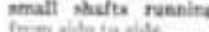

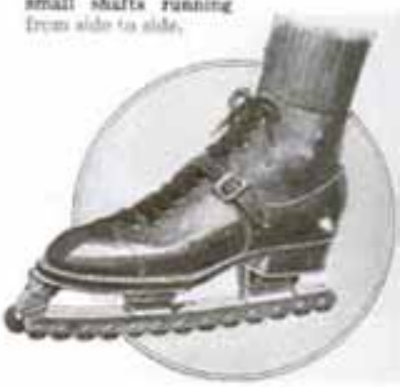

15. ábra A Harry Paulsen görkorcsolya. Az USA-ban bejegyzett szabadalmi szám 1:268385. Szabadalmaztatva 1918. 06. 04.(Mitskevichus, Роликовые коньки - roller skates (окончание), 2011)

\section{IRODALOM}

» Bonnefon, R. (2005. 02 21). Bienvenue sur la page de patinage de REB, History. Letöltés dátuma: 2012. 03 05, forrás: http://regis-bonnefon.chez-alice.fr: http://regis-bonnefon. chez-alice.fr/histoire-en.html » BuyVintage. (2008. 03 06). 1896 The Road Skate Co RITTER SKATES. Letöltés dátuma: 2012, forrás: 2ND BUYVINTAGE ONLINE AUCTION: 2012 ONWARDS: http:// buyvintage1.wordpress.com/page-15-1923-triumph-250ccround-tank/

» Herefordshire Roller skating Club. (2012). The History of the roller skate. Forrás: http://skatehereford.co.uk: http:// skatehereford.co.uk/Historyofrollerskating.aspx

» Karmelek, M. (2012. 03 19). Over 100 Years Later, an Old Invention Takes a New Spin. Letöltés dátuma: 2012. 03 29, forrás: http://blogs.scientificamerican.com/anecdotes-from-thearchive/: http://blogs.scientificamerican.com/anecdotes-fromthe-archive/2012/03/19/over-100-years-later-an-old-inventiontakes-a-new-spin/

» kzcrew.com. (2008). インラインスケートの歴史 - Inline Skate History. Forrás: http://kzcrew.com/modules/: http:// kzcrew.com/modules/sec_technique/index.php?content_id=3 » Landroller, I. (2012). Landroller. Letöltés dátuma: 2012. 10 03, forrás: Landroller: http://landroller.com/ » Mitskevichus, A. (2011. 04 28). Роликовые коньки - roller skates (окончание). Letöltés dátuma: 2012. 11 03, forrás: Очерки по истории изобретений: http://top100invent. blogspot.hu/2011/04/p-roller-skates_28.html » Mitskevichus, A. (2011). Очерки по истории изобретений. Forrás: http://top100invent.blogspot.com/search/label/\%D0 \%A0\%D0\%BE\%D0\%BB\%D0\%B8\%D0\%BA\%D0\%BE\%D 0\%B2\%D1\%8B\%D0\%B5\%20\%D0\%BA\%D0\%BE\%D0\%B D\%D1\%8C\%D0\%BA\%D0\%B8: http://4.bp.blogspot.com/ELz31CRkBMA/TajBFh1WoQI/AAAAAAAAAXg/e_P6pUAg_ wU/s1600/018_08b.jpg

» Mitskevichus, A. (2011. 04 16). Очерки по истории изобретений. Letöltés dátuma: 2012. 02 02, forrás: http:// top100invent.blogspot.com/: http://top100invent.blogspot. com/2011/04/p-roller-skates.html » Oldbike.eu. (2011. 02 07). 1896 PATIN BICYCLETTE Richard-Choubersky Road Skates. Letöltés dátuma: 2012. 04 03, forrás: http://oldbike.wordpress.com/: http://oldbike. wordpress.com/1896-richard-choubersky-road-skates/ » The Inline Planet. (2005). The Illustrated History of Inline Skate Design At the US Patent Office. Letöltés dátuma: 2012. 10 04, forrás: The Inline Planet: http://www.inlineplanet.com/ History/patentgallery.html » Wikipédia. (2012. 08 08). Nordic walking. Letöltés dátuma: 2012. 10 04, forrás: Wikipédia: http://hu.wikipedia.org/wiki/ Nordic_walking 